\section{Experimental clues for detecting biosignatures on Mars}

\section{J.-C. Viennet ${ }^{1,2 *}$, S. Bernard ${ }^{1}$, C. Le Guillou ${ }^{3}$, P. Jacquemot ${ }^{1,2}$ E. Balan', L. Delbes ${ }^{1}$, B. Rigaud ${ }^{4}$, T. Georgelin ${ }^{5}$, M. Jaber ${ }^{2}$}

Abstract

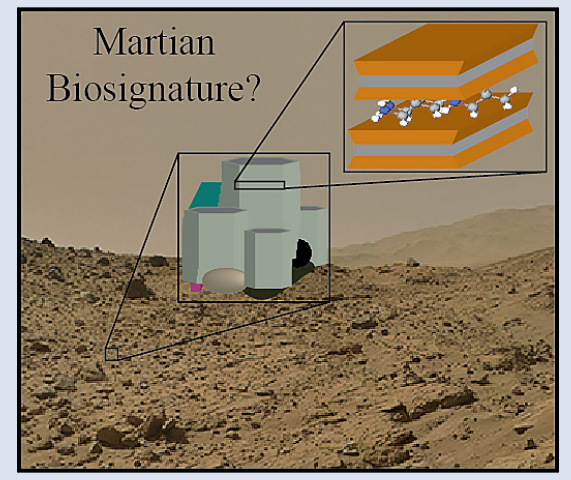

Forthcoming exploration of Mars aims at identifying fossil biosignatures within ancient clay-rich formations. The subsurface of Mars has mostly acted as a giant freezer for the last $4 \mathrm{Gyr}$, thereby preserving potential remains of martian life. Yet, volcanism and impactors have periodically triggered the circulation of hydrothermal fluids, inevitably causing alteration of potentially fossilised biogenic organic materials. It thus appears crucial to quantify the impact of hydrothermal processes on organic biogeochemical signals in the presence of clay minerals. Here, we submitted RNA to hydrothermal conditions in the presence of Mg-smectites. Results show heterogeneous organo-mineral residues, with sub-micrometric phosphates, carbonates and amorphous silica particles together with $\mathrm{Mg}$-smectites with interlayer spaces saturated by $\mathrm{N}$-rich organic compounds. Although the chemical structure of RNA did not withstand hydrothermal conditions, clay minerals efficiently trapped organic carbon, confirming the relevance of drilling for organic carbon in ancient martian sediments. In addition, the degradation of RNA in the presence of $\mathrm{Mg}$-smectites led to the precipitation of a quite uncommon mineral assemblage that could be seen as a biosignature per se. Martian targets exhibiting this mineral assemblage will thus constitute high priority and highly relevant candidates for sample return.

Received 25 February 2019 | Accepted 7 November 2019 | Published 27 November 2019

\section{Letter}

Life may have existed on Mars. In fact, some evidence suggest that conditions were favourable for life to exist on Mars during the Noachian ( 4.1 to $3.7 \mathrm{Ga})$, from both the standpoints of liquid water availability and metabolic energy sources (Grotzinger et al., 2014; Kral et al., 2014). Following previous successful missions that visited the red planet, upcoming exploration of Mars aims at identifying potential fossilised biosignatures (Mustard et al., 2013; Westall et al., 2015; Vago et al., 2017), with organic carbon obviously constituting the grail to be sought after (Summons et al., 2008; McMahon et al., 2018). To date, although macromolecular carbon has been detected within most of the martian meteorites (Steele et al., 2016, 2018), only small organic molecules including aromatic, aliphatic, chlorine- and sulfur-rich organic compounds have been measured on Mars (Biemann et al., 1977; Freissinet et al., 2015; Eigenbrode et al., 2018).

Because of the lack of global plate tectonic processes, traces of this life could be preserved in martian sedimentary rocks despite the continuous UV irradiation of the surface
(Cockell, 2002). In fact, the subsurface of Mars has acted as a giant freezer since the Noachian $(3.7 \mathrm{Ga})$ (Clifford et al., 2010). However, even if the surface of Mars has been relatively inactive compared to Earth, volcanism and impactors have periodically triggered the circulation of hydrothermal fluids, inevitably causing alteration of potentially fossilised biogenic organic materials (Abramov and Kring, 2005; Schwenzer and Kring, 2009; Osinski et al., 2013).

In the context of the massive international push for the astrobiological exploration of Mars, the forthcoming ExoMars and Mars2020 missions will explore the subsurface of ancient $(>3.7 \mathrm{Ga})$ clay-rich martian terrains that likely formed in the presence of water (Ehlmann et al., 2008; Mustard et al., 2013; Westall et al., 2015; Vago et al., 2017). Clay minerals, and smectites in particular, are the prime target of these missions because of their strong absorption capacity, low reactivity, and low permeability when compacted (Kennedy et al., 2002; Naimark et al., 2016; McMahon et al., 2018), giving them a high 'potential of biopreservation'. The presence of these minerals at landing sites is thus believed to maximise the chances of detecting diagnostic organic molecules.

\footnotetext{
1. Muséum National d'Histoire Naturelle, Sorbonne Université, CNRS, UMR 7590, Institut de Minéralogie, Physique des Matériaux et Cosmochimie, Paris, France

Laboratoire d'Archéologie Moléculaire et Structurale, CNRS UMR 8220, Institut des Matériaux de Paris, Sorbonne Université, F-75005 Paris, France

Université de Lille, CNRS, INRA, ENSCL, UMR 8207 - UMET - Unité Matériaux et Transformations, F-59000 Lille, France

Institut des Matériaux de Paris Centre, Sorbonne Université, F-75005 Paris, France

Laboratoire de Réactivité de Surface, CNRS, UMR 7197, Institut des Matériaux de Paris, Sorbonne Université, F-75005 Paris, France

Corresponding author (email: jean.christophe.viennet25@gmail.com)
} 
Nevertheless, little is known regarding the interactions between clay minerals and (biogenic or abiotic) organic compounds under hydrothermal conditions that may have existed in the subsurface of Mars. Better constraining the impact of hydrothermal processes on fossilised organic biosignatures thus appears fundamental in conducting the future search for traces of life on Mars with any reasonable degree of confidence. Only laboratory experiments can provide the necessary insights.

RNA is the most emblematic biogenic organic molecule used by all known living organisms, and potentially the most ancient replicating molecule on Earth according to the 'RNA world' hypothesis (Higgs and Lehman, 2014). Mg-smectites are one of the most widespread clay minerals present on Mars and on the future landing sites (Ehlmann et al., 2008; Vago et al., 2017). Here, we heated RNA at hydrothermal conditions in pure bi-distilled water in equilibrium with a $\mathrm{CO}_{2}$ atmosphere at $200{ }^{\circ} \mathrm{C}$ for 7 days in the presence of $\mathrm{Mg}$-smectites. We conducted additional experiments under the same conditions with RNA in the absence of $\mathrm{Mg}$-smectites and with $\mathrm{Mg}$-smectites in the absence of RNA to serve as controls. $\mathrm{A} \mathrm{CO}_{2}$ atmosphere was used to simulate Noachian martian atmosphere (Wordsworth, 2016). The water insoluble experimental residues were characterised at different scales using X-ray diffraction and advanced microscopy and spectroscopy tools.

Results show that the presence of $\mathrm{Mg}$-smectites considerably impacts the amount of carbon and nitrogen retrieved in the residues after the experiments. While only $7.8 \mathrm{wt}$ \% of the initial carbon and $1.7 \mathrm{wt}$. \% of the initial nitrogen are found in the organic residues of experiments conducted in the absence of smectite, $36.5 \mathrm{wt}$. \% of the initial carbon and 10.8 wt. \% of the initial nitrogen remain in the organo-mineral residues of the experiments conducted with $\mathrm{Mg}$-smectites. These amounts correspond to a mean N/C of 0.11 for the organic component and to TOC values as high as 6.5 wt. \% (Table 1), i.e. twice the values of most of the hydrocarbon source rocks on Earth (Bernard and Horsfield, 2014). As expected, the presence of clay minerals thus drastically maximises the chances of concentrating, preserving, and ultimately detecting organic molecules.

Table 1 Proportions of carbon and nitrogen (in mass).

\begin{tabular}{|l|c|c|c|}
\hline \multicolumn{1}{|c|}{ Sample } & RNA & $\begin{array}{c}\text { Mg- } \\
\text { smectites- } \\
\text { RNA- } \\
\mathrm{CO}_{2}-200{ }^{\circ} \mathrm{C}\end{array}$ & $\begin{array}{c}\text { RNA- } \\
\mathrm{CO}_{2}-200{ }^{\circ} \mathrm{C}\end{array}$ \\
\hline $\begin{array}{l}\text { Initial mass of organic } \\
\text { matter }(\mathrm{mg})\end{array}$ & - & 150 & 150 \\
\hline Final mass of sample $(\mathrm{mg})$ & - & 270 & 7.0 \\
\hline$\%_{\mathrm{wt}} \mathrm{C}$ & $31.6( \pm 0.07)$ & $6.4( \pm 0.07)$ & $52.9( \pm 0.07)$ \\
\hline Initial mass of $\mathrm{C}(\mathrm{mg})$ & & 47.4 & 47.4 \\
\hline Final mass of $\mathrm{C}(\mathrm{mg})$ & - & 17.3 & 3.7 \\
\hline$\%$ of $\mathrm{C}$ preserved & & 36.5 & 7.8 \\
\hline$\%{ }_{\mathrm{wt}} \mathrm{N}$ & $14.9( \pm 0.02)$ & $0.9( \pm 0.02)$ & $5.7( \pm 0.02)$ \\
\hline Initial mass of $\mathrm{N}(\mathrm{mg})$ & & 22.3 & 22.3 \\
\hline Final mass of $\mathrm{N}(\mathrm{mg})$ & - & 2.4 & 0.4 \\
\hline$\%$ of $\mathrm{N}$ preserved & & 10.8 & 1.7 \\
\hline
\end{tabular}

Surprisingly, even though the present experiments were conducted using pure $\mathrm{Mg}$-smectites and pure RNA, the organo-mineral residues are highly heterogeneous. In addition to $\mathrm{Mg}$-smectites, transmission electron microscopy investigations in STEM mode (scanning transmission electron microscopy) highlight the presence of Ca-carbonates and $\mathrm{Mg}$, $\mathrm{Ca}$ and Al-phosphates, together with particles of amorphous silica (Fig. 1). This occurrence of phosphates is attested by diagnostic peaks observed in the XRD pattern (Fig. 2) and the presence of carbonates is confirmed by diagnostic features in the XANES and MIR spectra (Figs. 1 and 2).

The organic carbon of the residues appears essentially coupled with Mg-smectites and exhibits a XANES spectrum very different from that of RNA (Fig. 1). The XANES spectrum of RNA presents a series of peaks attributed to nucleobases (aromatic and olefinic carbons $(285 \mathrm{eV})$, heterocycles $(285.9 \mathrm{eV})$, ketone and phenol groups (286.7 - $287.4 \mathrm{eV})$ ) and ribose (saturated carbons $(288.0 \mathrm{eV})$ and hydroxyl groups $(289.3 \mathrm{eV}))$. In contrast, the organic compounds coupled with smectites in the experimental residues mainly contain amide $(288.2 \mathrm{eV})$ and saturated aliphatic $(288.0 \mathrm{eV})$ groups, as well as aromatic and/or olefinic carbons $(285 \mathrm{eV})$ and ketone and/ or phenol groups $(287.4 \mathrm{eV})$. Occurrence of saturated aliphatic groups is also attested by diagnostic $\mathrm{C}-\mathrm{H}$ stretching bands observed in the ATR-FTIR spectrum (Fig. 2).

In addition to the compounds found with smectites $(\mathrm{N} / \mathrm{C}=0.11)$, the experimental residues also contain some rare organic masses $(\mathrm{N} / \mathrm{C}=0.15)$ whose spectra display peaks of aromatic and olefinic carbons $(285 \mathrm{eV})$, conjugated (hetero) cycles $(285.4 \mathrm{eV})$ and carboxylic groups $(288.4 \mathrm{eV})$, as well as some even rarer aromatic particles $(\mathrm{N} / \mathrm{C}<0.05)$ whose spectra only display peaks of aromatic and olefinic carbons $(285 \mathrm{eV})$ and conjugated (hetero)cycles (285.4 eV) (Fig. 1) (Le Guillou et al., 2018). These compounds are not present in high concentrations, the organic component of the residues essentially consisting of the compounds associated with Mg-smectites, explaining bulk $\mathrm{N} / \mathrm{C}$ values.

The crystal structure of the Mg-smectites does not suffer significant transformation during the experiments (same hkl reflections on the XRD pattern and similar IR bands related to $\mathrm{Mg}-\mathrm{OH}$ or Si-O vibrations; Fig. 2). However, the 001 reflection is shifted from 15.51 to $13.31 \AA$ (Fig. 2), indicating a modification of the interlayer spaces. The observed shift is consistent with the presence of organic molecules and/or a mixture of bi- and mono-hydrated cations in the interlayer space (Ferrage et al., 2005; Gautier et al., 2017). Bands at 1440 and $1580 \mathrm{~cm}^{-1}$ in the FTIR spectrum of experimental residues are consistent with the presence of $\mathrm{NH}_{4}{ }^{+}$and $\mathrm{R}-\mathrm{NH}_{3}{ }^{+}$groups, respectively.

The presence of ammonium in the interlayer spaces of smectites is excluded, however. In fact, for those exposed to high vacuum, the 001 reflections of the experimental residues and of the pristine $\mathrm{Mg}$-smectites saturated with $\mathrm{NH}_{4}{ }^{+}$ exhibit a markedly different behaviour (Fig. 2), showing that the interlayer spaces of these smectites are locked by N-rich organic compounds rather than by ammonium. Consistently with XANES data indicating N/C values of 0.11 for these compounds, XRD data show a 001 reflection at $13.55 \AA$ for the $\mathrm{Mg}$-smectites of the residues (Fig. 2) indicating the presence, within the interlayer spaces, of organic compounds containing up to 10 carbon atoms for $1 \mathrm{R}-\mathrm{NH}_{3}{ }^{+}$group (i.e. $\mathrm{N} / \mathrm{C}$ values of about 0.1) according to the alkylammonium method (Laird et al., 1989). Assuming that $\mathrm{R}-\mathrm{NH}_{3}{ }^{+}$groups totally compensate the loss of $\mathrm{Ca}^{2+}$, the $\mathrm{Mg}$-smectites contain $1.3 \mathrm{wt}$. \% of nitrogen, and thus 10.9 wt. \% of carbon $(\mathrm{N} / \mathrm{C}=0.1)$. Given that the residues exhibit a TOC of $6.5 \mathrm{wt} \%$, assuming that most of the organic compounds of the experimental residues are within the interlayer spaces of the $\mathrm{Mg}$-smectites leads to a proportion of approximately $60 \mathrm{wt}$. \% of $\mathrm{Mg}$-smectites in the residues, which is quite consistent with TEM data.

The formation of the observed mineral assemblage can be explained as follows (Fig. 3). Under hydrothermal conditions, the dissolution of the $\mathrm{Mg}$-smectites, together with the 


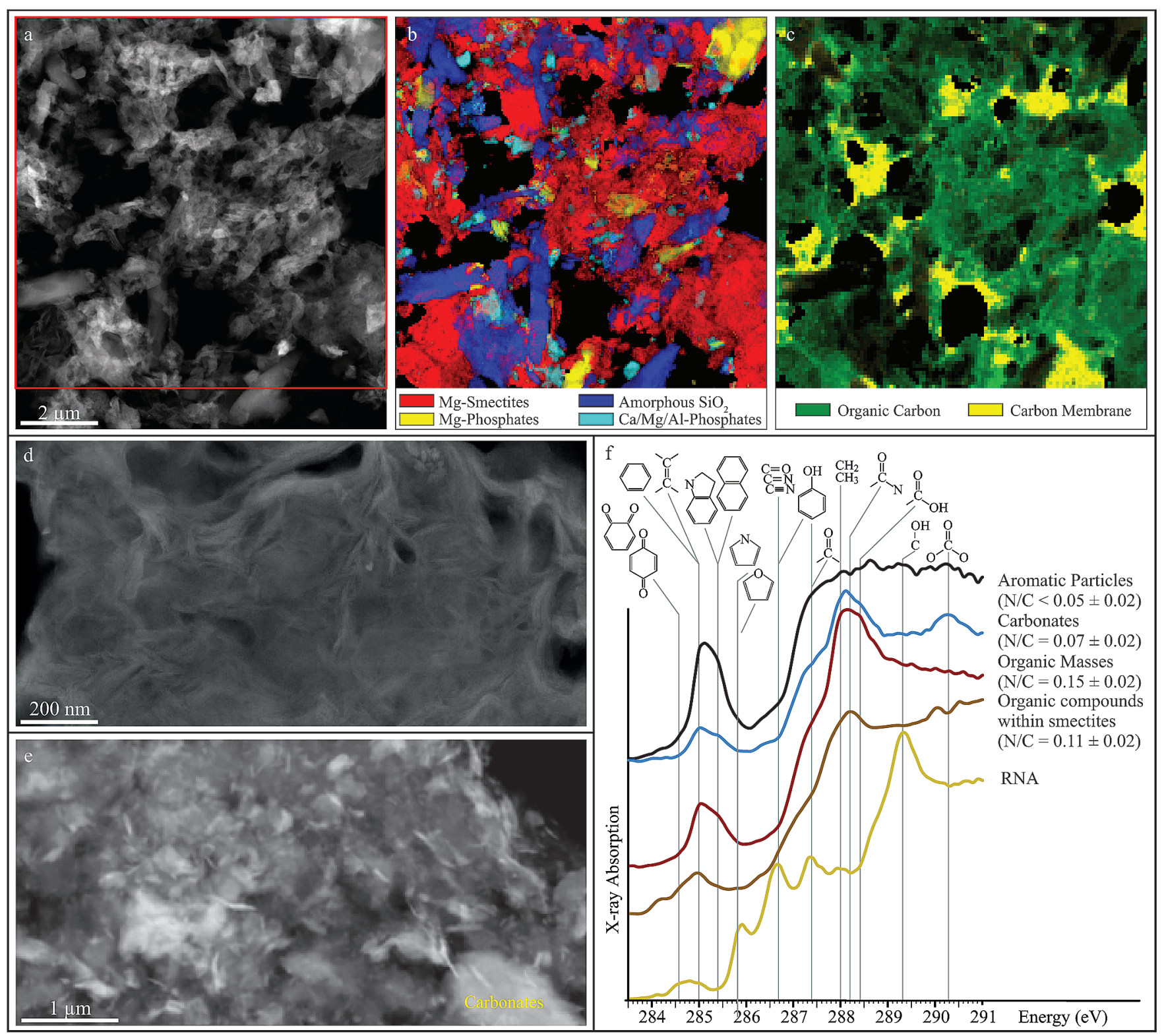

Figure 1 STEM and STXM characterisation of the experimental residues. (a) STEM image of the residues of experiments conducted under $\mathrm{CO}_{2}$ at $200{ }^{\circ} \mathrm{C}$ in the presence of Mg-smectites and RNA. (b,c) Maps of minerals and organic compounds (same area as a). (d) STEM images of Mg-smectites. (e) STEM image of sub-micrometric minerals embedded in organic masses. (f) XANES spectra of organic compounds encountered in the residues. The spectrum of RNA is shown for comparison.

interlayer cationic exchange, releases $\mathrm{Al}, \mathrm{Mg}$ and $\mathrm{Ca}$ in the system. Ca-carbonates then precipitate, the carbon source being either RNA degradation products (Sagemann et al., 1999) or the $\mathrm{CO}_{2}$ rich atmosphere (Viennet et al., 2017, 2019). Meanwhile, the phosphate mono-ester groups of RNA underwent hydrolysis, leading to the precipitation of $\mathrm{Al}, \mathrm{Ca}$ and Mg-phosphates (Fig. 3; Saxby, 2012). Amorphous $\mathrm{SiO}_{2}$ particles were formed, as in dissolution experiments (Robin et al., 2016). In parallel, the N-rich aliphatic organic compounds produced by the degradation of RNA are trapped mainly in the interlayer spaces of the remaining $\mathrm{Mg}$-smectites as a result of cationic exchange (Fig. 3). The $\mathrm{NH}_{3}{ }^{+}$groups of these organic compounds replace the initial $\mathrm{Ca}^{2+}$ cations in the interlayer spaces of the Mg-smectites (Laird et al., 1989).

Taken altogether, the results of the present experiments are of major importance for the upcoming astrobiological exploration of Mars. Although the organic compounds present in the residues do not carry any information on the chemical structure of the organic starting material, these experimental results demonstrate that clay minerals can efficiently trap organic carbon under hydrothermal conditions, providing strong support for the strategy of drilling for organic carbon in martian subsurface (Eigenbrode et al., 2018; McMahon et al., 2018).

As shown here, the hydrothermal degradation of $(\mathrm{N}, \mathrm{P})$-rich organic molecules in the presence of Mg-smectites leads to the precipitation of a quite uncommon mineral assemblage comprising sub-micrometric Ca-carbonates and ( $\mathrm{Al}, \mathrm{Mg}$, Ca)-phosphates, together with amorphous silica and clay-organic complexes. Such an assemblage will be stable under martian subsurface conditions for eons. Martian targets exhibiting this mineral assemblage will thus constitute high priority and highly relevant candidates for sample return because of the likelihood that they result from the hydrothermal degradation of $(\mathrm{N}, \mathrm{P})$-rich biogenic organic molecules. As a corollary, the presence and the nature of organic materials within martian rocks should not be the only 'biosignatures' to consider when searching for traces of life: the nature of the mineral assemblage may be even richer in information. 


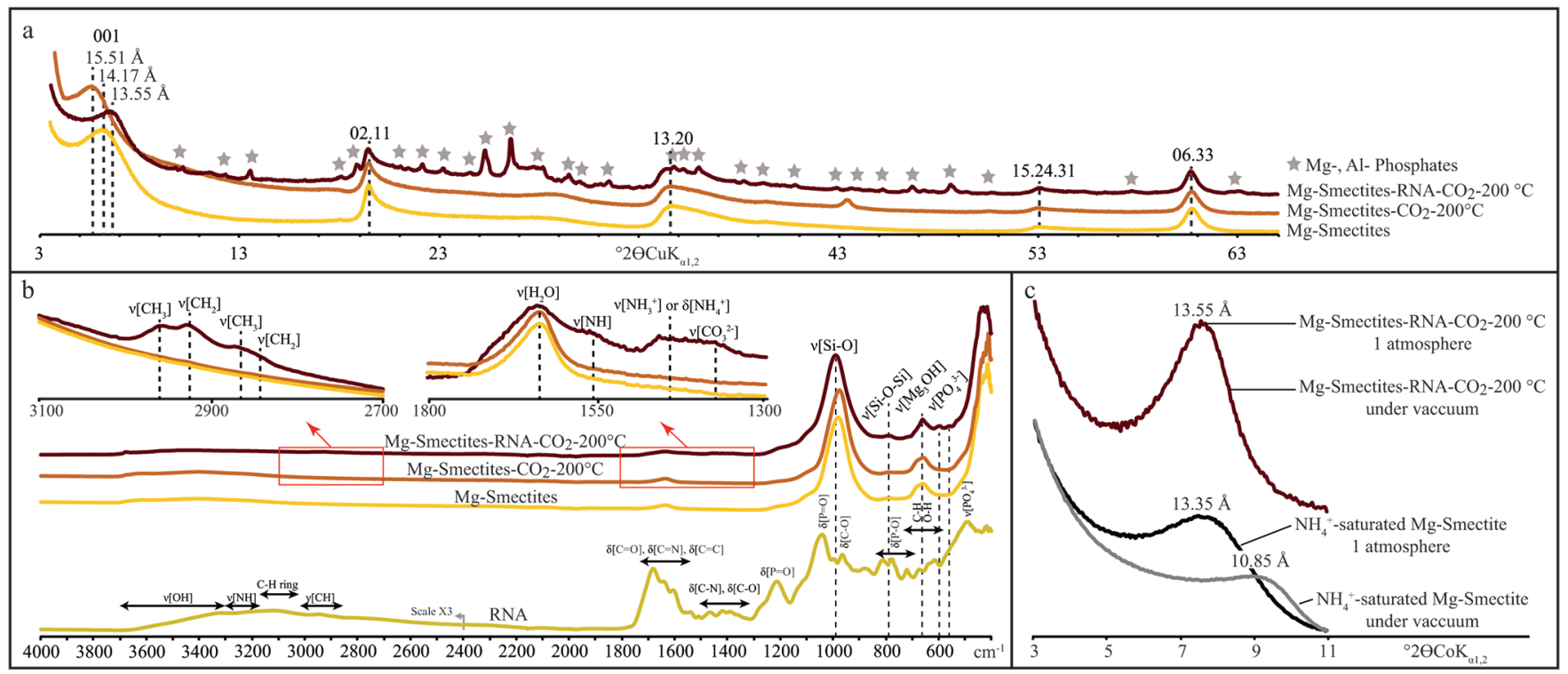

Figure 2 XRD and Mid-IR characterisation of the residues of experiments conducted under $\mathrm{CO}_{2}$ at $200{ }^{\circ} \mathrm{C}$ in the presence or absence of RNA. (a) Powder XRD patterns of the synthetic Mg-smectites and of the experimental residues. Values correspond to hkI reflections of the Mg-smectites. (b) Mid-infrared ATR spectra of the starting materials (RNA and Mg-smectites) and of the residues. (c) XRD patterns at 1 atmosphere and under vacuum of the pristine $\mathrm{Mg}$-smectites saturated with $\mathrm{NH}_{4}{ }^{+}$and of the residues. Values correspond to the 001 reflection.

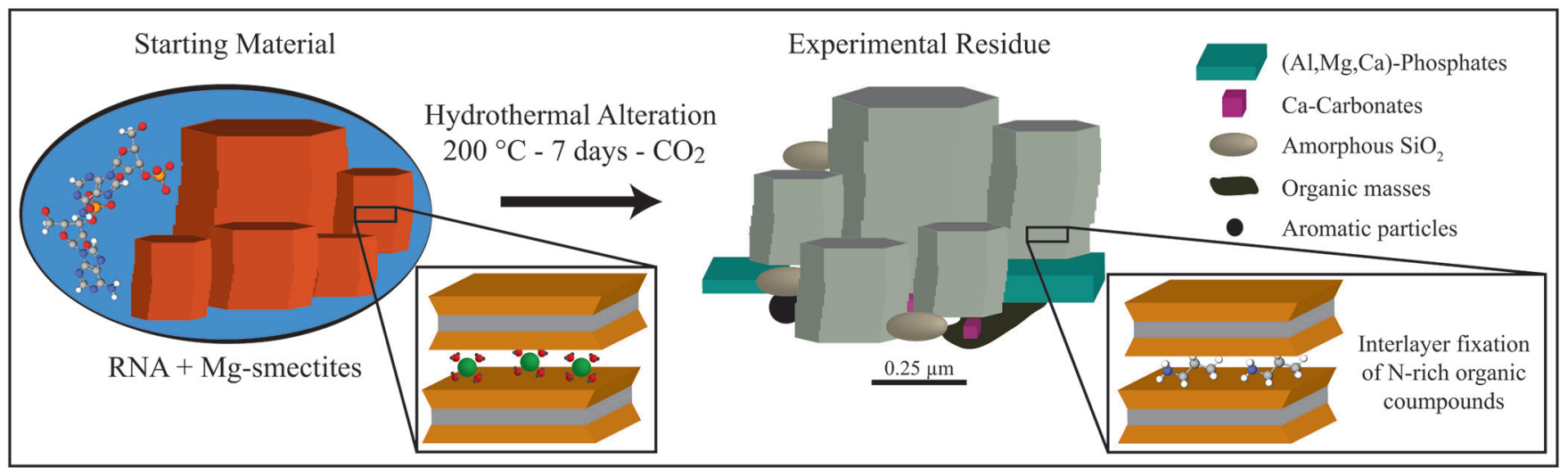

Figure 3 Schematic representation of the results of the present experiments.

In summary, the pilot experiments reported here provide new leads for the (indirect) detection of (biogenic) organic carbon in the martian subsurface. Extrapolating laboratory results to geological timescales is not straightforward (Alleon et al., 2017). Achieving a mechanistic understanding of biosignature taphonomy processes on Mars will require many additional experimental studies.

In addition to offering new perspectives for the search for traces of life on Mars, the present study also provides a strong rationale for the search for potential biosignatures on other planetary bodies, including rocky and/or icy ones (such as Ceres, Enceladus or Europa) on which hydrothermal systems and/or $\mathrm{N}$-rich clay minerals have recently been detected (Carrozzo et al., 2018; Nordheim et al., 2018; Marchi et al., 2019). As illustrated here, laboratory experiments are key steps to support astrobiological exploration seeking to provide evidence of the existence of extraterrestrial life.

\section{Acknowledgements}

The authors wish to acknowledge the workforce of the spectroscopic and X-ray diffraction facilities at IMPMC. Special thanks go to Stefan Stanescu and Sufal Swaraj for their expert support with the HERMES STXM beamline at SOLEIL, to Anne-Marie Blanchenet for her help during the Cryo-ultramicrotome section preparations and to François Baudin for his help with CHNS measurements. We gratefully acknowledge financial support from the programme Emergences Sorbonne Universités (Project MarsAtLab - PI: S. Bernard) and the DIM MAP (Project FossilEx - PI: M. Jaber). The authors thank also Dr. Roger Hewins for polishing the English. The TEM facility in Lille (France) is supported by the Conseil Régional du Nord-Pas de Calais, and the European Regional Development Fund (ERDF). The HERMES beamline (SOLEIL) is supported by the CNRS, the CEA, the Region Ile de France, the Departmental Council of Essonne and the Region Centre. The authors wish to acknowledge the Editor Pr. Liane G. Benning, as well as two anonymous reviewers, for their constructive comments that greatly improved the quality of this work.

\section{Editor: Liane G. Benning}

\section{Author Contributions}

JCV, SB and MJ designed the present study. JCV conducted the hydrothermal experiments. JCV performed CHNS 
measurements. JCV, CLG and PJ performed STEM analyses. JCV, SB and CLG performed STXM-XANES analyses. JCV and EB performed IR analyses. JCV and LD performed XRD analyses. All authors contributed to the interpretation of the results. JCV and SB wrote the manuscript, with critical inputs from CLG, EB and MJ.

\section{Additional Information}

Supplementary Information accompanies this letter at http:// www.geochemicalperspectivesletters.org/article1931.

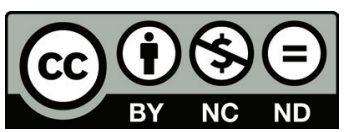

This work is distributed under the Creative Commons Attribution Non-Commercial No-Derivatives 4.0 License, which permits unrestricted distribution provided the original author and source are credited. The material may not be adapted (remixed, transformed or built upon) or used for commercial purposes without written permission from the author. Additional information is available at http://www.geochemicalperspectivesletters.org/ copyright-and-permissions.

Cite this letter as: Viennet, J.-C., Bernard, S., Le Guillou, C., Jacquemot, P., Balan, E., Delbes, L., Rigaud, B., Georgelin, T., Jaber, M. (2019) Experimental clues for detecting biosignatures on Mars. Geochem. Persp. Let. 12, 28-33.

\section{References}

ABRAMOV, O., KRING, D.A. (2005) Impact-induced hydrothermal activity on early Mars. Journal of Geophysical Research: Planets 110.

Alleon, J., Bernard, S., Le Guillou, C., Daval, D., Skouri-Panet, F., KugA, M., Robert, F. (2017) Organic molecular heterogeneities can withstand diagenesis. Scientific Reports 7, 1508

Bernard, S., Horsfield, B. (2014) Thermal Maturation of Gas Shale Systems. Annual Review of Earth and Planetary Sciences 42, 635-651.

Biemann, K., Oro, J., Toulmin, P., Orgel, L.E., Nier, A.O., Anderson, D.M., Simmonds, P.G., Flory, D., Diaz, A. V, Rushneck, D.R., BILLER, J.E., LAFLEUR, A.L. (1977) The search for organic substances and inorganic volatile compounds in the surface of Mars. Journal of Geophysical Research 82, 4641-4658

Carrozzo, F.G., De Sanctis, M.C., Raponi, A., Ammannito, E., Castillo-Rogez, J., Ehlmann, B.L., Marchi, S., Stein, N., Ciarniello, M., Tosi, F., Capaccioni, F., Capria, M.T., Fonte, S., Formisano, M., Frigeri, A., Giardino, M., Longobardo, A. Magni, G., Palomba, E., Zambon, F., Raymond, C.A., Russell C.T. (2018) Nature, formation, and distribution of carbonates on Ceres. Science Advances 4, e1701645.

Clifford, S.M., Lasue, J., Heggy, E., Boisson, J., McGovern, P., Max, M.D. (2010) Depth of the Martian cryosphere: Revised estimates and implications for the existence and detection of subpermafrost groundwater. Journal of Geophysical Research: Planets 115.

CockelL, C.S. (2002) The Ultraviolet Radiation Environment of Earth and Mars: Past and Present. In: Horneck, G., Baumstark-Khan, C. (Eds.) Astrobiology: The Quest for the Conditions of Life. Springer Berlin Heidelberg, Berlin, Heidelberg, 219-232.

Ehlmann, B.L., Mustard, J.F., Fassett, C.I., Schon, S.C., Head III, J.W., Des Marais, D.J., Grant, J.A., Murchie, S.L. (2008) Clay minerals in delta deposits and organic preservation potential on Mars. Nature Geoscience 1, 355

Eigenbrode, J.L., Summons, R.E., Steele, A., Freissinet, C., Millan, M., Navarro-GonzÁlez, R., Sutter, B., McAdam, A.C., Franz H.B., Glavin, D.P., Archer, P.D., Mahaffy, P.R., Conrad, P.G., Hurowitz, J.A., Grotzinger, J.P., Gupta, S., Ming, D.W., Sumner, D.Y., Szopa, C., Malespin, C., Buch, A., Coll, P. (2018) Organic matter preserved in 3-billion-year-old mudstones at Gale crater, Mars. Science 360, 1096 LP - 1101.

Ferrage, E., Lanson, B., SAKHarov, B.A., Drits, V.A. (2005) Investigation of smectite hydration properties by modeling experimental X-ray diffraction patterns: Part I. Montmorillonite hydration properties. American Mineralogist 90, 1358-1374.
Freissinet, C., Glavin, D.P., Mahaffy, P.R., Miller, K.E., Eigenbrode, J.L., Summons, R.E., Brunner, A.E., BuCH, A., SzOPA, C., ARCHER, P.D., Franz, H.B., Atreya, S.K., Brinckerhoff, W.B., Cabane, M., Coll, P., Conrad, P.G., Des Marais, D.J., DWorkin, J.P., FAirén, A.G., François, P., Grotzinger, J.P., KashyaP, S., Kate, I.L., Leshin, L.A., Malespin, C.A., Martin, M.G., MartinTorres, F.J., McAdaM, A.C., Ming, D.W., NAVARRO-GonZÁleZ, R., Pavlov, A.A., Prats, B.D., Squyres, S.W., Steele, A., Stern, J.C., Sumner, D.Y., SutTer, B., ZorZano, M.-P. (2015) Organic molecules in the Sheepbed Mudstone, Gale Crater, Mars. Journal of Geophysical Research: Planets 120, 495-514.

Gautier, M., Muller, F., Le Forestier, L. (2017) Interactions of ammonium-smectite with volatile organic compounds from leachates. Clay Minerals 52, 143-158.

Grotzinger, J.P., Sumner, D.Y., Kah, L.C., Stack, K., Gupta, S., Edgar, L., Rubin, D., Lewis, K., Schieber, J., Mangold, N., Milliken, R., Conrad, P.G., Desmarais, D., Farmer, J., Siebach, K., Calef, F., Hurowitz, J., Mclennan, S.M., Ming, D., Vaniman, D., CRise, J., Vasavada, A., Edgett, K.S., Malin, M., Blake, D., Gellert, R., Mahaffy, P., Wiens, R.C., Maurice, S., Grant, J.A., Wilson, S., Anderson, R.C., BeEgle, L., Arvidson, R., Hallet, B., Sletten, R.S., Rice, M., Bell, J., Griffes, J., Ehlmann, B., ANderson, R.B., Bristow, T.F., Dietrich, W.E., Dromart, G., Eigenbrode, J., Fraeman, A., Hardgrove, C., Herkenhoff, K., Jandura, L., Kocurek, G., Lee, S., Leshin, L.A., Leveille, R., Limonadi, D., Maki, J., McCloskey, S., Meyer, M., Minitti, M., Newsom, H., Oehler, D., OKon, A., PAlucis, M., PARKer, T., Rowland, S., Schmidt, M., SQuYres, S., Steele, A., Stolper, E., Summons, R., Treiman, A., Williams, R., Yingst, A., Team, M.S.L.S. (2014) A Habitable Fluvio-Lacustrine Environment at Yellowknife Bay, Gale Crater, Mars. Science 343.

Kennedy, M.J., Pevear, D.R., Hill, R.J. (2002) Mineral Surface Control of Organic Carbon in Black Shale. Science 295, 657 LP - 660.

Kral, T.A., Birch, W., LaVender, L.E., Virden, B.T. (2014) Potential use of highly insoluble carbonates as carbon sources by methanogens in the subsurface of Mars. Planetary and Space Science 101, 181-185.

LAIRD, D.A., SCOTT, A.D., FEnTON, T.E. (1989) Evaluation of the alkylam monium method of determining layer charge. Clays and Clay Minerals $37,41-46$

Le Guillou, C., Bernard, S., De la Pena, F., Le Brech, Y. (2018) XANeS Based Quantification of Carbon Functional Group Concentrations. Analytical Chemistry 90, 8379-8386

Marchi, S., Raponi, A., Prettyman, T.H., De Sanctis, M.C., Castillo-Rogez, J., Raymond, C.A., Ammannito, E., Bowling, T., Ciarniello, M., Kaplan, H., Palomba, E., Russell, C.T., Vinogradoff, V., Yamashita, N. (2019) An aqueously altered carbon-rich Ceres. Nature Astronomy 3, 140-145.

McMahon, S., Bosak, T., Grotzinger, J.P., Milliken, R.E., Summons, R.E., Daye, M., Newman, S.A., Fraeman, A., Williford, K.H., Briggs, D.E.G. (2018) A Field Guide to Finding Fossils on Mars. Journal of Geophysical Research: Planets 123, 1012-1040.

Mustard, J.F., M. Adler, A. Allwood, D.S. Bass, D.W. Beaty, J.F. Bell III, W.B. Brinckerhoff, M. Carr, D.J. Des Marais, B. Drake, K.S. Edgett, J. Eigenbrode, L.T. Elkins-Tanton, J.A. Grant, S. M. Milkovich, D. Ming, C. Moore, S. Murchie, T.C. Onstott, S.W, A.T. (2013) Report of the Mars 2020 Science Definition Team. Posted July, 2013, by the Mars Exploration Program Analysis Group (MEPAG) at http://mepag.jpl.nasa.gov/reports/MEP/Mars_2020_SDT_ Report_Final.pdf.

Naimark, E., Kalinina, M., Shokurov, A., Boeva, N., Markov, A., ZAYTSEVA, L. (2016) Decaying in different clays: implications for softtissue preservation. Palaeontology 59, 583-595.

Nordheim, T.A., Hand, K.P., Paranicas, C. (2018) Preservation of potential biosignatures in the shallow subsurface of Europa. Nature Astronomy 2, 673-679.

Osinski, G.R., Tornabene, L.L., Banerjee, N.R., Cockell, C.S., Flemming, R., IzaWA, M.R.M., MCCutcheon, J., PARnell, J., Preston, L.J., Pickersgill, A.E., Pontefract, A., SAPErs, H.M., Southam, G. (2013) Impact-generated hydrothermal systems on Earth and Mars. Icarus 224, 347-363.

Sagemann, J., Bale, S.J., Briggs, D.E.G., Parkes, R.J. (1999) Controls on the formation of authigenic minerals in association with decaying organic matter: an experimental approach. Geochimica et Cosmochimica Acta 63, 1083-1095

SAXBY, J. (2012) The significance of organic matter in ore genesis. Geochemical Studies 2, 111 
SCHWENZER, S.P., KRING, D.A. (2009) Impact-generated hydrothermal systems capable of forming phyllosilicates on Noachian Mars. Geology 37, 1091-1094.

Steele, A., McCubbin, F.M., Fries, M.D. (2016) The provenance, formation, and implications of reduced carbon phases in Martian meteorites. Meteoritics \& Planetary Science 51, 2203-2225.

Steele, A., Benning, L.G., Wirth, R., Siljeström, S., Fries, M.D., Hauri, E., Conrad, P.G., Rogers, K., Eigenbrode, J., Schreiber, A., Needham, A., Wang, J.H., McCubbin, F.M., Kilcoyne, D., Rodriguez Blanco, J.D. (2018) Organic synthesis on Mars by electrochemical reduction of CO2. Science Advances 4, eaat5118.

Summons, R.E., Albrecht, P., McDonald, G., Moldowan, J.M. (2008) Molecular Biosignatures. In: Botta, O., Bada, J.L., Gomez-Elvira, J., Javaux, E., Selsis, F., Summons, R. (Eds) Strategies of Life Detection. Springer US, Boston, MA, 133-159.

Vago, J.L., Westall, F., Pasteur Instrument Teams and Other Contributors, L.S.S.W.G., Coates, A.J., Jaumann, R., KorableV, O., Ciarletti, V., Mitrofanov, I., Josset, J.-L., De Sanctis, M.C., Bibring, J.-P., Rull, F., Goesmann, F., Steininger, H., Goetz, W., Brinckerhoff, W., Szopa, C., Raulin, F., Westall, F., EdWARds, H.G.M., Whyte, L.G., FAirén, A.G., Bibring, J.-P., Bridges, J., Hauber, E., Ori, G.G., Werner, S., Loizeau, D., Kuzmin, R.O., Williams, R.M.E., Flahaut, J., Forget, F., Vago, J.L., Rodionov, D., Korablev, O., Svedhem, H., Sefton-Nash, E., KmineK, G., LOREnZONI, L., JOUdRIER, L., MiKhaILOV, V., ZASHCHIRINSKIY, A., Alexashkin, S., Calantropio, F., Merlo, A., Poulakis, P., Witasse, O., Bayle, O., Bayón, S., Meierhenrich, U., Carter, J., García-Ruiz, J.M., Baglioni, P., Haldemann, A., Ball, A.J., Debus, A., Lindner, R., Haessig, F., Monteiro, D., Trautner, R., Voland, C., Rebeyre, P., Goulty, D., Didot, F., Durrant, S., Zekri, E., Koschny, D., Toni, A., Visentin, G., Zwick, M., van Winnendael, M., Azkarate, M., Carreau, C., Team, the E.P. (2017) Habitability on Early Mars and the Search for Biosignatures with the ExoMars Rover. Astrobiology 17, 471-510.

Viennet, J.-C., Bultel, B., RiU, L., Werner, S.C. (2017) Dioctahedral Phyllosilicates Versus Zeolites and Carbonates Versus Zeolites Competitions as Constraints to Understanding Early Mars Alteration Conditions. Journal of Geophysical Research: Planets 122.

Viennet, J.-C., Bultel, B., WeRner, S.C. (2019) Experimental reproduction of the martian weathering profiles argues for a dense Noachian $\mathrm{CO}_{2}$ atmosphere. Chemical Geology 525, 82-95.

Westall, F., Foucher, F., Bost, N., Bertrand, M., Loizeau, D., Vago, J.L., KMineK, G., Gaboyer, F., Campbell, K.A., BréHéret, J.-G., Gautret, P., Cockell, C.S. (2015) Biosignatures on Mars: What, Where, and How? Implications for the Search for Martian Life. Astrobiology 15, 998-1029.

WordsworTH, R.D. (2016) The Climate of Early Mars. Annual Review of Earth and Planetary Sciences 44, 381-408. 